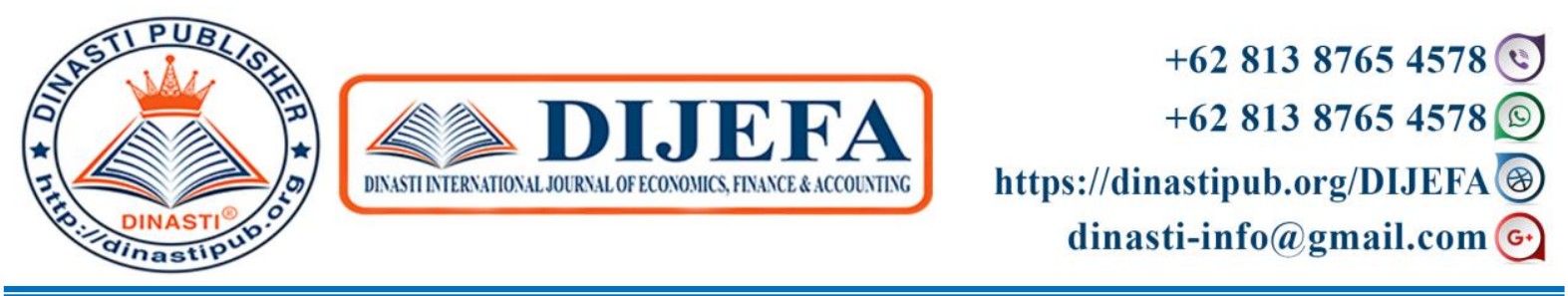

\title{
MODEL OF CONSUMER TRUST ON TRAVEL AGENT ONLINE: ANALYSIS OF PERCEIVED USEFULNESS AND SECURITY ON RE- PURCHASE INTERESTS (CASE STUDY TIKET.COM)
}

\author{
Hazimi Bimaruci Hazrati Havidz ${ }^{1)}$ Agung Hudaya $^{2)}$, Hapzi Ali $^{3 \text { ) }}$ \\ ${ }^{1)} \mathrm{Ph} . \mathrm{D}$ Student, Wuhan University of Technology, 205 Luoshi road, Wuhan, Hubei, China, \\ ${ }^{2)}$ Universitas Mercubuana, Jakarta, Indonesia
}

\begin{tabular}{|c|c|}
\hline $\begin{array}{l}\text { Corresponding author: first author } \\
\text { E-mail: } \\
\text { hazimi.bimaruci@ gmail.com } \\
\text { agunghudaya24@gmail.com }\end{array}$ & $\begin{array}{l}\text { Abstract: Technological development is very rapid, } \\
\text { many things are very influential with the presence of } \\
\text { the internet, many consumers are spoiled by online } \\
\text { shopping, with this it will make it easier for } \\
\text { transactions between sellers and buyers. Starting from } \\
\text { the search for goods, to make payment transactions. } \\
\text { But with the internet, in addition to making it easier for } \\
\text { buyers and sellers, but also creating new problems, } \\
\text { with the convenience, it will make it easier for } \\
\text { competitors to do the same. Competitors will more } \\
\text { easily seize customers, and customers will also more } \\
\text { easily go to other sellers, therefore the question arises, } \\
\text { how to make repurchase intention occur. One business } \\
\text { player who sees the internet as a new market share in } \\
\text { attracting consumers is the online travel agent } \\
\text { business. In the beginning, this travel business was } \\
\text { only done conventionally. Then the travel business } \\
\text { also utilizes technology in marketing activities. With } \\
\text { this research will find out whether there is an influence } \\
\text { between perceived usefulness, with trust, then whether } \\
\text { there is a perceived influence on repurchase intention, } \\
\text { and whether there is an influence of trust with } \\
\text { repurchase intention. The sampling technique was } \\
\text { purposive sampling. Using the Slovin formula, a } \\
\text { sample of } 100 \text { customers was obtained, the margin of } \\
\text { error set was } 10 \% \text { or } 0.10 \text {. Quantitative analysis } \\
\text { methods with SEM analysis tools and Smart PLS and } \\
\text { SPSS tools. } \\
\text { Keywords: perceived usefulness, trust, repurchase } \\
\text { intention }\end{array}$ \\
\hline
\end{tabular}




\section{INTRODUCTION}

The internet was originally developed by the US in the mid-19th century, and was originally used limited to military purposes. In today's developed world, the internet is almost becoming a primary need. The services offered by the internet are even more complete, communicative and pampering consumers in the sense of internet access. ADSL (asymmetric Digital Subscriber Line) technology which has been popular in recent years has made the internet a necessity that can be enjoyed 24-hour internet access. In the early days, internet usage was only limited to sending electronic mail (E-Mail). But along with the development of hardware and software that is very fast and fast, the material delivered via the internet web is also experiencing very rapid development as well, where the material created is not limited to text only, but can also be in the form of images, sound, video, streaming, to interactive, such as chat, video converence, and so forth (Sumargono, 2011).

As for the history of the internet in Indonesia itself, it began in the early 1990s. At that time the internet network in Indonesia was better known as the community network, where the spirit of cooperation, kinship and mutual cooperation was very warm and felt among the perpetrators. But along with its development, the internet now feels more commercial and individual in some of its activities, especially those involving internet commerce (Gustino, 2011). This is, of course, due to the increase in internet users themselves, so many business players see this as a new opportunity to increase new market share by doing business trading via the internet. Based on APJII 2017 data, it is known that the growth of internet users in Indonesia is growing rapidly, which is where each year always experiences a significant increase. For more details, the growth of internet users in Indonesia from year to year can be seen in the graph below.

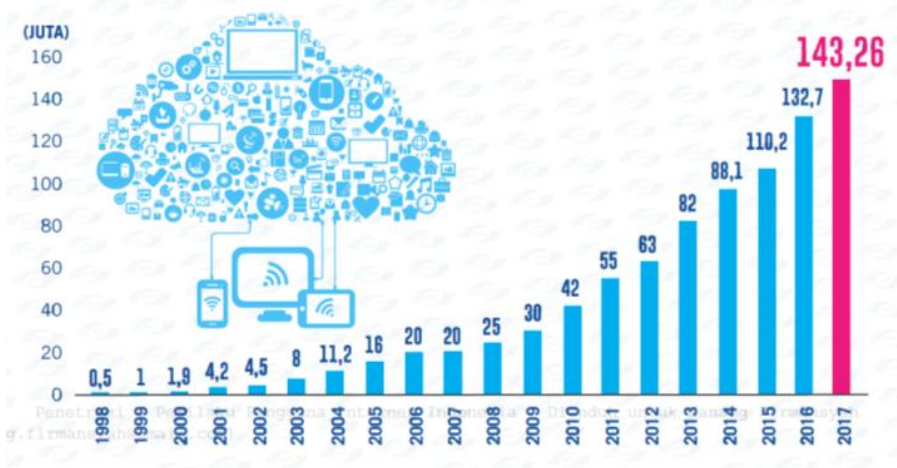

Figure 1. Graph of Growth of Internet Users in Indonesia

Based on the graph above, it can be seen that the growth of internet users has indeed increased quite rapidly, namely in 1998 where only 0.55 million people used the internet, 19 years later it increased to reach 143.26 million population. Based on these figures, it is not surprising that there are indeed many business players who take advantage of this as a new opportunity in expanding market share.

Indonesian consumers like online shopping along with the increasing internet penetration in Indonesia Consumers like to read product or service reviews, and look for detailed information related to 
products or services needed (nielson.com, 2014). This fact can be concluded that Indonesian people have been able to adapt to the emergence of e-commerce and are getting used to shopping online. So to search and purchase or make transactions online for products or services is a common thing done by the public. "Purchasing via the internet is one of the most rapidly growing forms of shopping" Grunert and Ramus (2005). This statement can be interpreted that developments in making online purchases have changed the way consumers buy products or services. However, although the development can be said to be fast, the e-commerce market is still relatively small and how to attract consumers to buy back online (online repurchase intention) is still the main focus of online retailers (Johnson \& Hult, 2008). At present, online repurchase intention has become an important issue in business-to-customer (B2C) e-commerce.

Online retailers recognize that the lack of face-to-face interaction with consumers and less reliable information, causes online shopping to face more challenges compared to off-line shopping, including mistrust, low switching costs, uncertainty, and rapid spread of word-of-mouth (Zhang et al, 2011), It can be seen that consumer interest to repurchase online (online repurchase intention) is a very important factor in e-commerce, and online retailing competes with each other to retain consumers and increase company profitability. According to Reichheld and Sasser (1990), online repurchase intention is a source of profit for a company.

One business player who sees the internet as a new market share in attracting consumers is the online travel agent business. In the beginning, this travel business was only done conventionally,

Menurut data Top Brand Index Tiket.com merupakan salah satu merek yang mendapatkan Top Brand pada tahun 2016 pada bidang online booking tiket pesawat dan travel, namun pada tahun-tahun berikutnya tiket.com tidak mendpatkn predikat Top Brand. Pada tahun 2017 tiket.com menduduki posisi ketiga, dan pada tahun 2018 Tiket.com kembali mengalami penurunan dan cukup jauh yaitu mendapatkan peringkat ke-empat, dan untuk nomor satu selalu Traveloka yang menjadi salah satu competitor terkuat tiket.com, Top Brand Index merupakan hasil riset terhadap konsumen. Riset dilakukan melalui survei dari Frontier Consulting Group disebelas kota besar di Indonesia dan menggunakan parameter yang diukur berdasarkan top of mind share, top of market share dan top of commitment share.

TOP BRAND INDEX

SITUS ONLINE BOOKING TIKET PESAWAT DAN TRAVEL

\begin{tabular}{|c|c|c|c|c|c|}
\hline \multicolumn{2}{|l|}{2018} & \multicolumn{2}{|l|}{2017} & \multicolumn{2}{|l|}{2016} \\
\hline Traveloka.com & $45.70 \%$ & Traveloka.com & $78.50 \%$ & Traveloka.com & $74.80 \%$ \\
\hline Trivago.co.id & $6.50 \%$ & Pegipegi.com & $2.70 \%$ & Tiket.com & $10.30 \%$ \\
\hline Pegipegi.com & $3.10 \%$ & Tiket.com & $1.60 \%$ & Trivago.co.id & $3.70 \%$ \\
\hline Tiket.com & $2.80 \%$ & Wego.co.id & $1.20 \%$ & Utiket.com & $3.20 \%$ \\
\hline
\end{tabular}


Figure 2 Top Brand Index Online Site Booking Aircraft and Travel

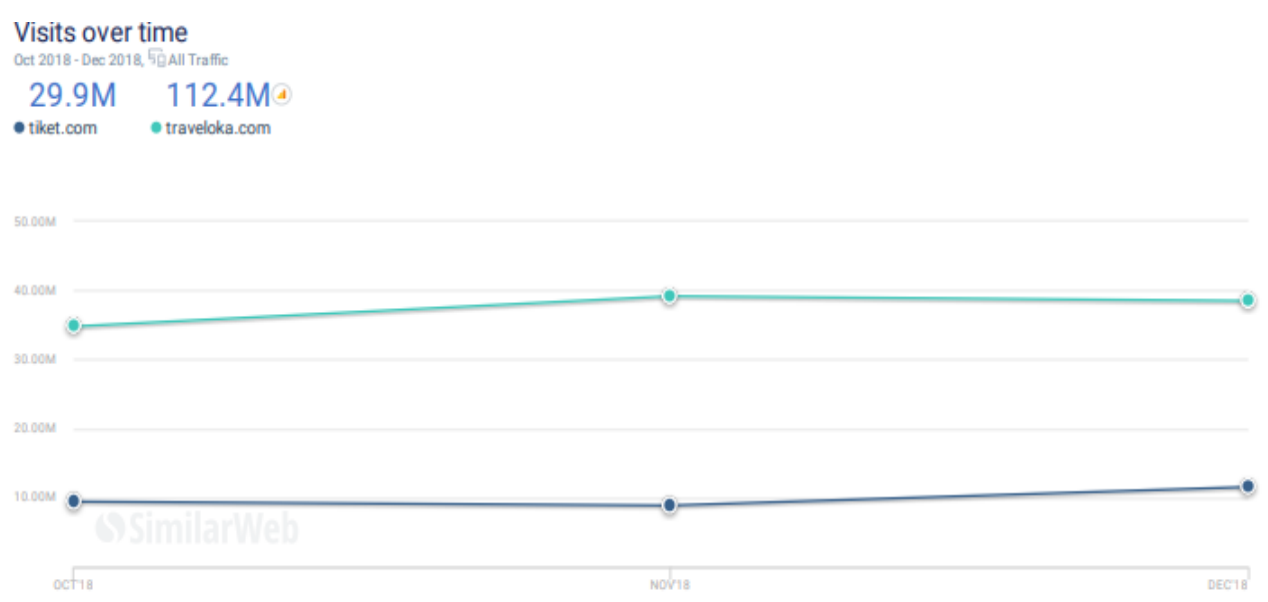

Figure 3 Visitor data for Ticket Online Agent 2018

In 2018, it can be seen that Tiket.com has experienced a decline at the end, and has increased again in December during the holiday season. Despite the increase in Tiket.com only got $29.9 \mathrm{~m}$ and that was quite far from its competitors who got 112.4M. Based on Figure 1.3, it is known that the average number of Tiket.com monthly visitors is seen to be unstable in 2018 .

\section{Identification of problems}

a) Identification of the problems in this study are as follows: competition in the world of online travel agent business is increasingly fierce where there are new entrants such as pegipegi.commerce and e-commerce that are starting to explore online ticketing

b) declining share of the brand top index in Tiket.com in the last few years which indicates a decline in popularity and has implications for consumer buying interest

c) there are security concerns that consumers worry about that can affect consumer buying interest

d) features in use (usefulness) that are not easy to use that can affect consumer buying interest.Tujuan Penelitian

The objectives of this study are as follows:

a. Analyzing the effect of perceived usefulness on Consumer Trust

b. Analyzing the effect of Security on Consumer Trust

c. Analyzing the effect of Trust on the Repurchase Intention

\section{LITERATURE REVIEW}

\section{Perceived Usefulness}

Davis in Sianadewi et al (2017: 106) defines perceived usefulness with "the degree to which a person believes that using a particular system would enhance his or her job performance." In the context of online purchases, perceived usefulness is the level where consumers believe that they will feel certain benefits or benefits if they make an expenditure at an online store. Perceived usefulness is defined as the extent to which a person believes that the use of a particular information system will improve its performance. From this definition it is known that the usefulness of perception is a belief about the decision making process. If someone 
feels that the system is useful then he will use it. Conversely, if someone feels that the information system is less useful then he will not use it (Santoso, 2012: 4).

Perceived usefulness can be said to be the benefit gained from shopping online on a site. Perceived usefulness can affect the attitude towards online shopping consumers and also purchase intention (Sianadewi et al, 2017: 105). The usefulness of perceived (perceived usefulness) is the extent to which someone believes that using a technology will improve its performance. From this definition it can be seen that the usefulness of perception is a belief about the decision making process. If someone feels that the system is useful then he will use it. Conversely, if someone believes that the information system is less useful then he will not use it (Zahra and Tadulako, 2011). Jogiyanto (2008) suggested that the definition of perceived usefulness as the extent to which an individual believes using a technology will improve his work performance. If the individual considers the information media useful then he will use it. Conversely, if the individual favors the media information is less useful then he will not use it.

Wen et al in Trisnawati et al (2012: 129) define perceived usefulness as consumers' assessment of the benefits of product information that is needed and felt when shopping at web-based stores. Indicators of perceived usefulness are:

a. The internet makes it easy to shop quickly.

b. The internet makes better purchasing decisions.

c. Internet as a more useful shopping.

d. Internet shopping saves money.

e. The internet is easier to make purchases.

\section{Security}

According to Park and Kim in Alwafi and Magnadi (2016: 4) security is defined as the ability of online stores to control and maintain security of data transactions. As a new marketing channel, E-commerce contains more uncertainty and risk than conventional purchases. This is because the seller and buyer do not meet each other during the transaction. Security can be guaranteed by providing a privacy statement and information about the security of the shopping mechanism and by displaying a logo from a trusted third party. For example, displaying a third-party logo that has been proven to guarantee security protection and has also been proven to significantly affect how customers perceive the trust of a vendor (Jiang et al in Cussoy, et al, 2013: 25-26).

Security perception is classified as an objective and subjective security problem. Objective security refers to the statement of security policy and technical protection, while subjective security refers to the overall security felt by consumers (Chellappa and Pavlou in Wijaya and Jasfar, 2014: 44). Security as the ability of online stores to control and maintain security of data transactions. Indicators of security are (Raman Arasu and Viswanathan in Alwafi and Magnadi (2016: 6):

1. a. Safety Guarantee

2. b. Data confidentiality.

\section{Trust}

Trust is the foundation of business. A business transaction between two or more parties will occur if each of them trusts each other. This trust cannot just be recognized by other parties / business partners, but must be built from scratch and can be proven. Trust has been considered as a catalyst in various transactions between sellers and buyers so that customer satisfaction can be realized as expected (Yousafzai, Pallister \& Foxall in Juniwati, 2015: 
142). Consumer confidence in the internet at an online shop occurs because consumers are getting aroused by their needs and curiosity more and more in the search for information to get what they want. The main concern of marketers is the sources of information that become a reference for consumers and the strong influence of each source there is a purchase decision (Kotler and Keller. 2009: 235).

The trust factor is a key factor in every online sale and purchase. Only customers who have the trust and dare to make transactions through internet media. Therefore, if there is no foundation of trust between the seller and the buyer, there will be no transaction in the world of ecommerce, let alone know if the product sold and offered by the seller is a pseudo product, in the sense that the product being sold is still in the shadow of the seller (Baskara and Hariyadi, 2014).

Trust occurs when one party believes in the other party's actions. Indicators of trust are (Trisnawati et al, 2012: 129):
a. Transaction security
b. Website can protect privacy
c. Good service online vendor
d. Online vendors can be trusted
e. Trusted online shop

\section{Repurchase Intention}

Repurchase intention is a post-purchase consumer action. The occurrence of satisfaction and dissatisfaction post consumer purchases of a product will affect subsequent behavior. If consumers are satisfied, it will indicate a higher possibility to repurchase the product (Kotler \& Keller, 2012). According to Simamora in Hamka (2010: 2) interest in buying a product arises because there is a basis of trust in the product marketing and a broad range of other factors, companies that can achieve and maintain differentiation will be companies that perform above the average in the industry if the price premium exceeds extra costs needed to be unique.

According to Hasan (2013: 131) repeat intention to buy can be identified through the following indicators:

a. Transactional interest, that is a person's tendency to buy products.

b. Referential interest, that is one's tendency to refer to others.

c. Preferential interest, which is an interest that describes the behavior of someone who has a primary preference on a product, this preference can only be replaced if something happens with the product's preference.

d. Explorative interest, this interest illustrates the behavior of someone who is always looking for information about the product he is interested in and is looking for information to support the positive qualities of the same product.

As according to Kotler and Armstrong (2011: 135-150) the main factors that influence one's interest to make a repeat purchase, are as follows:

a. Culture factor

A person's culture and social class can influence one's interest in making a purchase. Consumers have perceptions, desires and behaviors that are learned from childhood, so that in the end will form different perceptions in each consumer. Nationalities, religions, racial groups and geographical factors also affect each individual.

b. Psychological factors

Includes individual learning experiences about events in the past, and the influence of individual attitudes and beliefs. Learning experience can be defined as a change in behavior due to previous experience. The emergence of consumer interest in making repeat purchases 
is strongly influenced by individual learning experiences and consumer learning experiences that will determine buying actions and decision making.

c. Personal factors

Personality, age, occupation, economic situation and lifestyle of the consumer itself will affect the perception and decision making in buying. Therefore, the role of restaurants is important in providing good service to consumers. This personal factor includes self-concept. The concept of self can be defined as the way we see ourselves and in a certain time as a picture of the wages that we think about. In relation to repurchase interests, restaurants need to create the situation consumers expect. Similarly, providing and serving consumers with products in accordance with what consumers expect.

d. Social factors

Includes the fad group factor (small reference group). Fanciful group is defined as a group of people who influence the attitudes, opinions, norms and behavior of consumers. These groups are a collection of families, certain groups or people. In analyzing repurchase interests, family factors play a role as decision makers, initiative makers, influencers in purchasing decisions, determinants of what is bought, who makes purchases and who becomes users. The influence of the reference group on repurchase interest, among others, in determining the products and brands they use that are in accordance with the aspirations of the group. The effectiveness of the effect of repurchase intention of the group is highly dependent on the quality of production and the information available to consumers.

Tjiptono in Trisnawati et al (2012: 129) defines online repurchase intention as the customer's desire to repurchase for the future. Indicators of repurchase intention are:

a. Plan to buy the same product.

b. Plan to try another product.

c. Plan to buy more of the same product or other products.

\section{Framework}

Based on the research objectives, literature review, previous research and the relationship between variables, the analytical framework in this study is presented in the form of Figure 1. Where the variable quality of the product is an independent variable, the purchase variable is the dependent variable and the purchasing decisions as intervening variables, or variables that mediate between independent variables with the dependent variable.

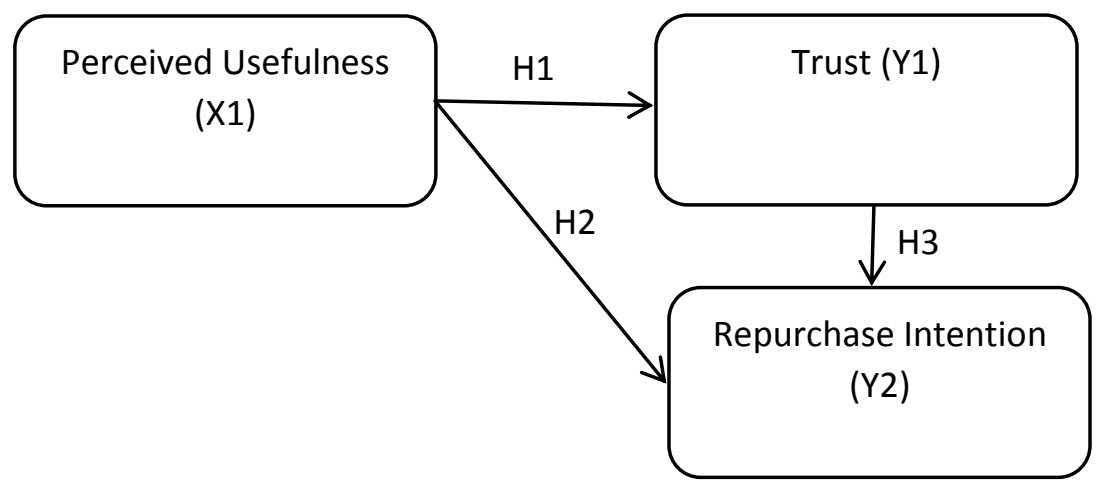

\section{Hypothesis}

Based on the problem examined, then a hypothesis is drawn as follows:

H1 : Perceived usefulness influence Trust

H2 : Perceived usefulness influence Purchase intention

H3 : Trust affect Repurchase intention 


\section{RESEARCH METHODS}

This study aims to examine the effect of a number of independent variables including, perceived usefulness, safety, consumer confidence and influence on repurchase intention. This data was obtained from the results of a survey conducted by distributing questionnaires.

The method of analysis of this study is a quantitative method and its analysis tool with SEM Before being analyzed by Path analysis, the instrument test (questionnaire) is tested first with the validity and reliability and Hypothesis tests. SEM analysis aids with the Smart PLS 3.0 application.

Process and product quality as independent variables, purchasing decision as intervening variables and repurchase as dependent variables. To test intervening variables the path analysis method is used, asan extension of multiple liniear regression analysis.

The method can be illustrated as shown in Figure 3.2. above with the path structure and sub structure as below:

$$
\begin{aligned}
& \mathrm{Y}=\mathrm{Pyx}_{1 .} \mathrm{X}_{1}+\mathrm{Pyx}_{2 .} \mathrm{X}_{2}+\mathcal{E}_{1} \\
& \mathrm{Z}=\mathrm{Pzx}_{1 .} \mathrm{X}_{1}+\mathrm{PzX}_{2 .} \mathrm{X}_{2}+\mathrm{Pzy} . \mathrm{Y}+\varepsilon
\end{aligned}
$$

Note: $\mathrm{X} 1=$ Perceived usefulness $; \mathrm{Y} 1=$ Trust $; \mathrm{Y} 2=$ Repurchase Intention $\varepsilon=$ epsion (other factors that influence)

\section{FINDINGS AND DISCUSSION}

\section{Research result}

There are three values that must be considered at this stage, namely convergent validity, discriminant validity, and composite reliability.

Convergent validity, the correlation between the score of reflexive indicators and the latent variable score. This research uses loading 0.5 to 0.6 is considered sufficient, because it is the initial stage of developing the measurement scale and the number of indicators per construct is not large, namely 2 (two) to 4 (four) indicators.

Discriminant validity, reflexive indicator measurement based on cross loading with its latent variables. Another method is by comparing the square root of average variance extracted (AVE) values of each construct with the correlation between other constructs in the model. If the initial measurement values of the two methods are better than the other construct values in the model, it can be concluded that the construct has a good discriminant validity value or vice versa. Accordingly, it is recommended that the measurement value be greater than 0.50 .

Composite reliability, a block indicator that measures the internal consistency of construct indicators, shows the degree to which it indicates common latent (unobserved). The construct is declared reliable if it has a composite reliability value above 0.70 and Cronbach's alpha above 0.60 even though it is not an absolute standard.

\section{Convergent Validity}

Convergent validity is used to determine instrument items that can be used as indicators of overall latent variables. The results of this test are measured based on the value of the loading factor ( outer loading) of the construct indicator. The following convergent validity test results are presented in the table.

Table 1. Table of Convergent Validity Test Results .

\begin{tabular}{cccc}
\hline Variable & Indicator & Outer Loadings & Information \\
\hline Perceived & X2.1 & 0.865 & Valid \\
usefulness & X2.2 & 0.719 & Valid \\
& X2.3 & 0.838 & Valid \\
& X2.4 & 0.872 & Valid
\end{tabular}




\begin{tabular}{cccc}
\hline & X2.5 & 0.851 & Valid \\
\hline Trust & Y1.1 & 0.872 & Valid \\
& Y1.2 & 0.787 & Valid \\
& Y1.3 & 0.810 & Valid \\
& Y1.4 & 0.842 & Valid \\
& Y1.5 & 0.867 & Valid \\
& Y1.6 & 0.832 & Valid \\
\hline Repurchase & Y2.1 & 0.837 & Valid \\
intention & Y2.2 & 0.844 & Valid \\
& Y2.3 & 0.817 & Valid \\
& Y2.4 & 0.894 & Valid \\
& Y2.5 & 0.789 & Valid \\
& Y2.6 & 0.834 & Valid \\
& Y2.7 & 0.794 & Valid \\
\hline
\end{tabular}

Source: Data processed from Smart PLS output

The table shows that all outer loading factors have values greater than 0.5 . So that this measurement can be concluded has met the requirements of convergent validity. The convergent validity of the measurement model using reflective indicators is assessed based on the outer loading factor of the indicators that measure the construct. In this study there are 5 constructs with a number of indicators ranging from 3 to 10 indicators with a scale of 1 to 5 .

If the correlation coefficient is equal to 0.3 or more (at least 0.3 ) then the instrument is declared valid, and invalid if the correlation coefficient is smaller than 0.3 (Sugiyono, 2006) states based on the results of the loading factor above, it is concluded that the construct which has a dominant loading factor above 0.5 has a good convergent validity .

Validity test is also performed by testing methods comparing the value of the square root of average variance extracted $(A V E)$ in each construct with the correlation between other constructs contained in the model.

Table 2 . Testing Results Table AVE

\begin{tabular}{lc}
\hline \multicolumn{1}{c}{ VARIABLES } & $\begin{array}{c}\text { Average Variance } \\
\text { Extracted (AVE) }\end{array}$ \\
\hline Perceived usefulness & 0.690 \\
Trust & 0.698 \\
Repurchase intention & 0.689 \\
\hline Data precedsedrom S
\end{tabular}

Source: Data processed from Smart PLS output

\section{Composite Reliability and Cron bach's Alpha}

Besides the construct validity test, a construct reliability test is also measured by composite reliability and Cronbach's alpha from the indicator block that measures the construct. The following are the results of testing the reliability and cronbach's alpha composite from Smart PLS: 
Table 2 . Composite Reliability and Cron bach's Alpha tables

\begin{tabular}{lcc}
\hline \multicolumn{1}{c}{ Variable } & Cronbach's Alpha & $\begin{array}{c}\text { Composite } \\
\text { Reliability }\end{array}$ \\
\hline Perceived usefulness & 0.887 & 0.917 \\
Trust & 0.913 & 0.933 \\
Repurchase intention & 0.925 & 0.939 \\
\hline \multicolumn{2}{c}{ Source: Data processed from Smart PLS output }
\end{tabular}

The construct is declared reliable if it has a composite reliability value above 0.70 and Cronbach's alpha above 0.60. From the results of SmartPLS output above all constructs have composite reliability values above 0.70 .

The measurement model for the validity and reliability test, the coefficient of determination of the model and the path coefficient for the equation model, can be seen in the following figure

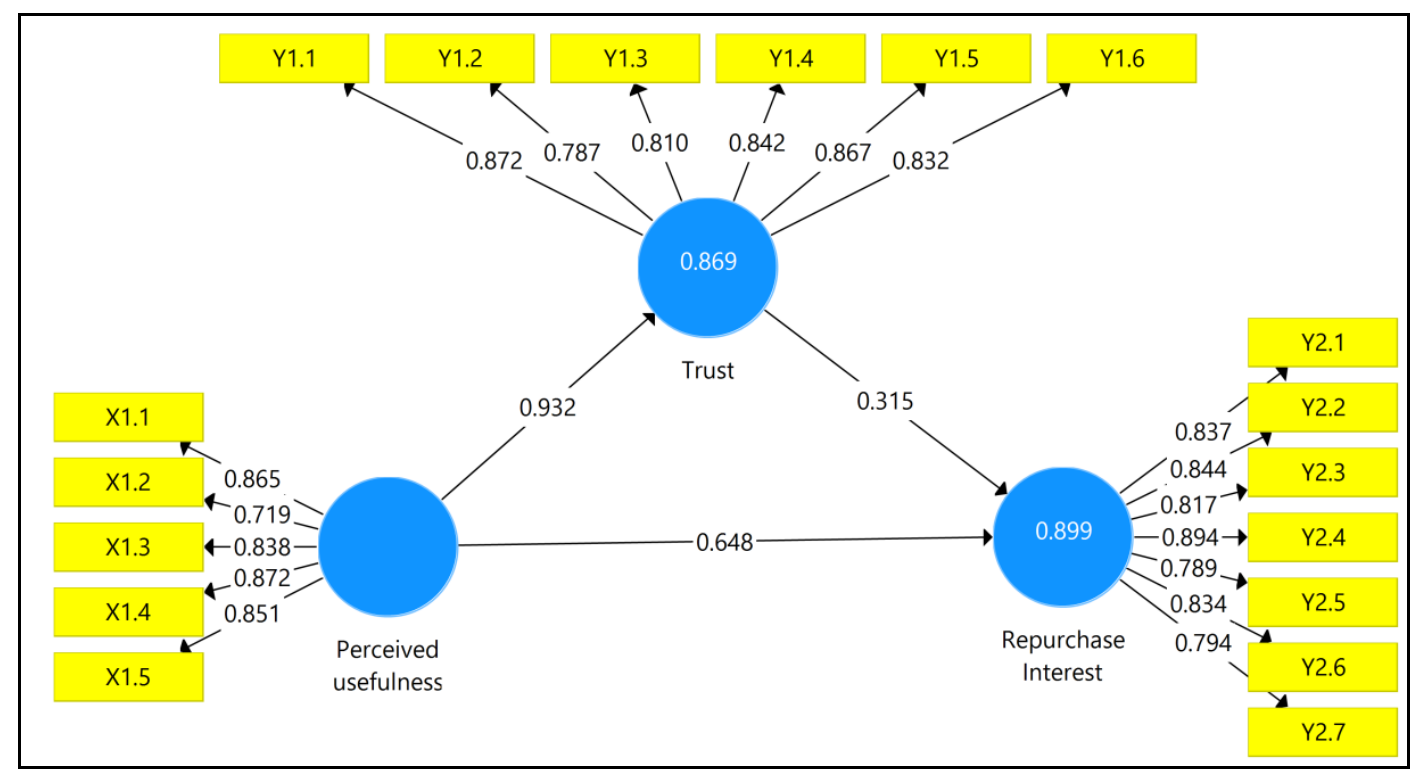

Figure 2. PLS Algorithm

Sumber: Source: Data processed from Smart PLS output

\section{Structural Model Testing (Inner Model)}

Structural model in PLS evaluated using $\mathrm{R}^{2}$ for the dependent variable and the coefficient of the path for the independent variables were then assessed the significance based on the value of $t$ statistic of each path. The structural model of this research can be seen in the following figure: 


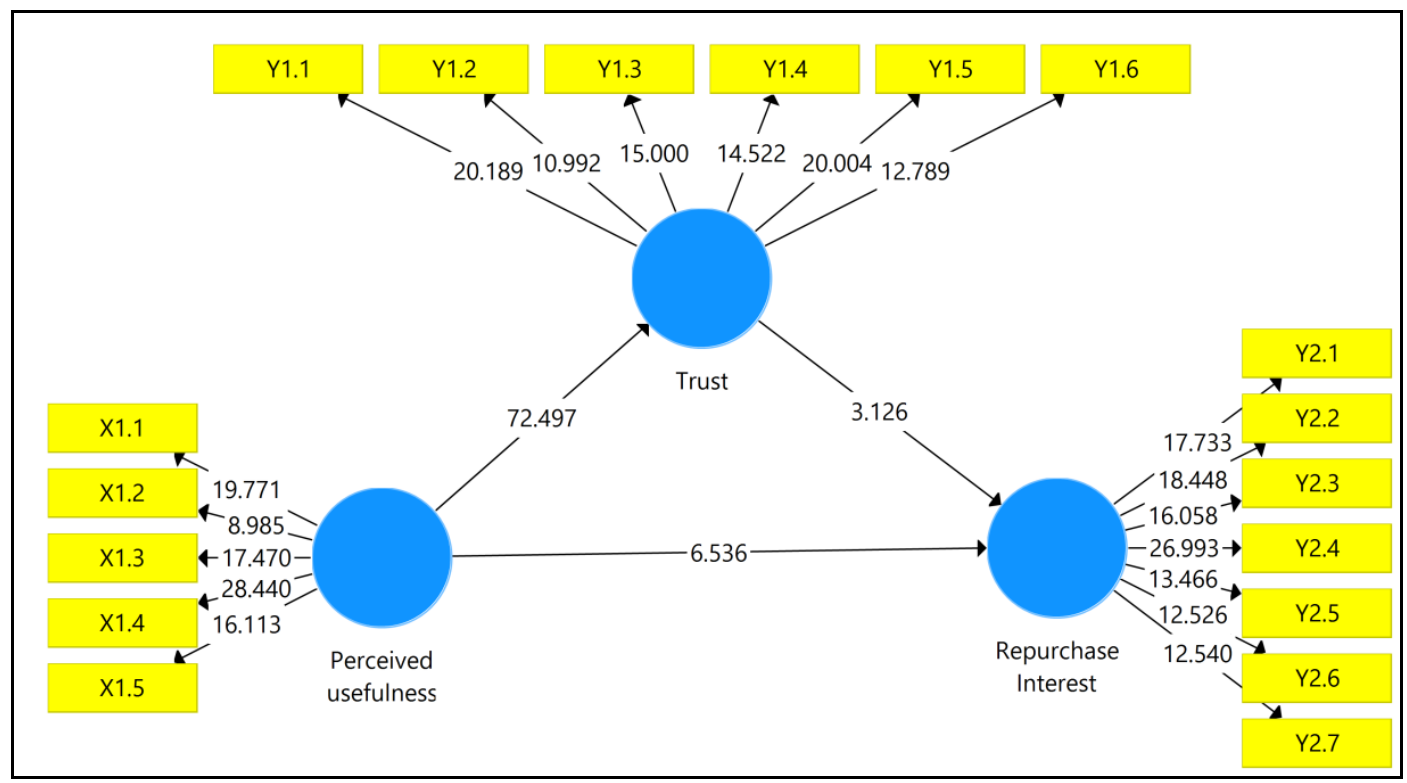

Figure 3. Display of PLS Bootstrapping Results

Source: Data processed from Smart PLS output

$\mathrm{R} 2$ values for each endogenous variable in this study can be seen in Table

Table 3. R-Square table

\begin{tabular}{lcc}
\hline Variable & R Square & R Square \\
Adjusted
\end{tabular}

Source: Data processed from Smart PLS output

$\mathrm{R}$ Square Value of Trust (Y1) of 0.899 shows a correlation, perceived usefulness. And R Repurchase Intention Value (Y1) of 0.869 shows a double correlation (perceived usefulness and Trust)

\section{Goodness of Fit}

In the next stage the model evaluation will be carried out through goodness of fit. Goodness of fit assessment is known from the $Q$-Square value. Value $Q$-Square has the same meaning as the coefficient of determination ( $R$-Square ) in the regression analysis, where the higher the Q-Square, then the model can be said to be more fit to the data. The results of the calculation of the values of QSquare are as follows:

$$
\begin{aligned}
\text { Q-Square = } 1-[(1-0,899) & \times \\
= & 1-(1-0,896)] \\
= & 1-0.010504 \\
= & 0.98
\end{aligned}
$$

Based on the calculation above, the $Q$-Square value of 0.98 is obtained. This shows the amount of diversity of research data that can be explained by the research model is $98 \%$, while the remaining $2 \%$ is explained by other factors that are outside this research model. Based on these results, the model in this study can be stated to have had an excellent goodness of fit .

Other variables or other factors that can influence purchasing decisions include service quality and a significant positive effect on purchasing decisions ( Anggita, R., \& Ali, H. 2017 ), brand trust 
has a positive and significant effect on purchasing decisions Rizky, Muhammad, et. al (2015), brand equity has a positive and significant effect on purchasing decisions Asih, Ratih Kartini (2013), etc.

Table 4 . Path Coefficients table (Mean, STDEV, t-Value)

\begin{tabular}{lcccc}
\hline \multicolumn{1}{c}{ Variable } & $\begin{array}{c}\text { Original } \\
\text { Sample } \\
(\boldsymbol{O})\end{array}$ & $\begin{array}{c}\boldsymbol{T} \\
\text { Statistics }\end{array}$ & $\begin{array}{c}\boldsymbol{P} \\
\text { Values }\end{array}$ & $\begin{array}{c}\text { Significance } \\
\text { Level }\end{array}$ \\
\hline Perceived usefulness $->$ Trust & 0.932 & 72.947 & 0,000 & $<0.05$ \\
Perceived usefulness $->$ Repurchase intention & 0.648 & 6.536 & 0,000 & $<0.05$ \\
Trust $>$ Repurchase intentinon & 0.315 & 3.126 & 0,002 & $<0.05$ \\
\hline Source Deta
\end{tabular}

Source: Data processed from Smart PLS output

Based on the table above it can be seen that the measurement model formed is the Equation Model as below:

$\mathrm{Y} 1=\mathbf{0 . 8 5 3 X} 1$

$\mathrm{Y} 2=0.424 \mathrm{X} 1+0.557 \mathrm{Y} 1$

Where,

$\mathrm{X} 1=$ Perceived usefulness

$\mathrm{Y} 1=$ Trust

$\mathrm{Y} 2=$ Repurchase intention

The equation above can be interpreted as follows:

1. Perceived usefulness Variables have a positive direction coefficient on trust

2. Perceived usefulness Variables have a positive direction coefficient on Repurchases intention

3. Trust Variable has a positive coefficient direction on Repurchase intention

\section{Hypothesis testing}

\section{1) The Effect of Perceived usefulness on Trust}

In the first hypothesis it is proven that the perceived usefulness variable has a significant positive effect on consumer trust (trust). Perception of usefulness (perceived usefulness) is the extent to which a person believes that using a particular system will improve the performance of his work or in the context of this study refers to the extent to which consumers believe that by using the online travel agent ticket.com site can improve their travel planning.

This means that a consumer's perceived usefulness can significantly influence his trust in an online travel agent site. This is in line with research conducted by Agag (2016) which revealed that the perceived usefulness variable can be the predecessor or antecedent of the consumer confidence variable (trust) and has a significant effect in research on consumer trust in using travel websites in Egypt.

According to Benamati et al (2010) perceived usefulness plays an important role in the adoption of technology from conventional to internet or ecommerce business and fostering consumer trust. A good perception of the usefulness of an online travel agent site to increase the productivity of consumer travel planning. This is also in line with the results of Roca (2009) research that perceived usefulness has a significant direct effect on consumer trust in financial business through online media. 


\section{2) The Effect of Perceived usefulness on Repurchases Intention}

In the third hypothesis, perceived usefulness is proven to have a positive influence on consumers' repurchase intention. This is in line with the research of Aren et al (2013) which states that the perception of usefulness is a significant driver of consumers to make repetitive or repeat purchases.

The results of Chiu's (2009) study state that consumers will tend to make a purchase or re-transact if the process is more beneficial. Consumers who have experienced an efficient and useful shopping experience will feel the perception of good usability and will encourage it to do the shopping process again in the future.

The greater the perceived usefulness value for food consumers, the more likely they are to return and make a repeat purchase. This is also in line with research by Har Lee (2011) who found a positive correlation between perceived usefulness of consumers and interest in repurchasing on e-commerce sites.

\section{3) The Influence of Trust Against Repurchases Intention}

In the fifth hypothesis the results of research prove that consumer trust (trust) has a positive effect on consumer repurchase intention (repurchase intention). This is in line with the results of the study of Chiu et al (2009) which states that consumer trust (trust) can predict repurchase intention positively.

In general, consumer confidence (trust) is seen as the confidence of consumers to the seller relating to the good intentions of the seller (benevolence), expertise (competence) and honesty or integrity of the seller (integrity). In the context of online business this is important because there is no direct interaction between seller and buyer. Consumer confidence (trust) will create good confidence in the seller and will increase the tendency of consumers to buy back. This is in line with the research of Hsu (2015) which states that consumer trust has a positive significance to repurchase intentions which are moderated by consumer habits. Aren (2013) also found that consumer trust has a positive significance on repurchase intention because trust is considered as one of the factors that can minimize risk perception and can be an effective fast way to attract buyers to make repetitive purchases. .

\section{CONCLUSION AND SUGESTION}

The conclusions obtained from the results of research and discussion regarding this thesis are as follows:

1. Perceived usefulness (perceived usefulness) has a positive and significant effect on consumer trust (trust). The better the level of perceived usefulness, the better the level of consumer trust in online travel agents.

2. Perceived usefulness (perceived usefulness) has a positive and significant effect on repurchase intention. The better the level of perceived usefulness, the better the level of consumer repurchase intention.

3. Consumer trust (trust) has a positive and significant effect on repurchase intention. The better the level of consumer confidence (trust), the better the level of consumer repurchase intention (repurchase intention).

\section{Suggestions}

\section{a. Practically}

Based on the results of research in this thesis shows that perceived usefulness and online trust significantly influence online repurchase intention. The researcher provides the following practical suggestions: 
1. The application of perceived usefulness and online trust is considered to be very well implemented by the Tiket.com application. However, the Tiket.com application should also further enhance the value proposition by providing users with benefits or benefits when accessing and purchasing airplane tickets through the Tiket.com application. Not only that, Tiket.com application also has high trust and reputation regarding trusted online flight ticket search application in the eyes of users. This must be maintained and improved by the Tiket.com application because businesses that operate in the online auction are highly at risk with cybercrime.

2. The Tiket.com application should conduct regular market research to find out what changes are happening to the market and consumers. In this case, the variable perceived security has a significant but lower effect for online repurchase intention on the Tiket.com application. In several previous studies, perceived security is one of the factors that can affect online repurchase intention in e-commerce. This must be analyzed related to the absence of influence on online repurchase intention and is used as a basis for analyzing other supporting factors that can affect online repurchase intention on the Tiket.com application. Not only that, competitor factors can also be considered to analyze existing problems and use them as a strategy in controlling the flight ticket market share online.

\section{REFERENCE}

Agussalim, M. P., Rezkiana, A., \& Ali, H. (2016). Analysis Work Discipline and Work Spirit toward Performance of Employees (Case Study Tax Office Pratama Two Padang). International Journal of Economics and Research. Vol, 13, 2541-2556

Ali, H. (2010). Membangun Citra Perbankan Melalui IT \& CRM: Untuk Meningkatkan Loyalitas Nasabah. Yogyakarta: Hasta Cipta Mandiri.

Ali, H., \& Wangdra, T. (2010). Sistem Informasi Bisnis. Jakarta: Badouse Media

Ali, Hasan . 2013. Marketing dan Kasus-Kasus Pilihan. Yogyakarta. CAPS (Center For Academic Publishing Service)

Alwafi, Fachrizi. Magnadi, Rizal. 2016. "Pengaruh Persepsi, Keamanan, Kemudahan Bertransaksi, Kepercayaan Terhadap Toko Dan Pengalaman Berbelanja Terhadap Minat Beli Tokopedia.com." Journal of Management 5: 1-15.

Antini A. Dan Trisnawati. 2015. Hubungan Pengetahuan, Sikap dan Budaya Akseptor KB terhadap Pemilihan Metode AKDR di Wilayah Kerja Puskesmas Anggadita Kabupaten Karawang. Jurnal Kebidanan volume 5 No. 1 Tahun 2015

Henry Simamora, 2010, Manajemen Sumber Daya Manusia, Gramedia, Jakarta

Kotler, Philip . (2012). Prinsip-prinsip Pemasaran .Edisi Ketigabelas Jilid I. Erlangga. Jakarta.

Kotler, Philips \& Amstrong, Gary (2012) . Prinsip-prinsip Pemasaran Edisi 13, Jilid 1, Jakarta : Erlangga.

Kottler, Philip, Keller, L Kevin (2012). Manajemen Pemasaran. Edisi 12. Jakarta: Erlangga.

Raman, Arasu. Annamalai, Viswanathan. 2011. "Web Services and E-Shopping Decisions :

A Study on Malaysian E-Consumer." Business Information System, 54-60

Santoso, Singgih. 2012. Panduan Lengkap SPSS Versi 20. Jakarta: PT Elex Media Komputindo.

Sugiyono. (2009). Metode Penelitian Bisnis. Alfabeta. Bandung.

Sugiyono. (2011). Metode Penelitian Pendidikan (Pendekatan Kuantitatif, Kualitatif dan $R \& D)$. Alfabeta. Bandung. 
Sumargono. 2012. Pengembangan Soft Skill dan Hard Skill Dalam Pembelajaran

Kewirausahaan Pengaruhnya Terhadap Kemampuan Merancang Prospek Usaha.

Jombang : Univ. Pesantren Tinggi Darul Ulam Sumarsono. 2004. Metode Riset

Sumber Daya Manusia. Yogyakarta : Graha Ilmu

Tjiptono, Fandy \& Gregorius Chandra (2011). Service, Quality \& Satisfaction. Edisi 3, Andi: Yogyakarta.

Tjiptono, Fandy (2014). Strategi pemasaran. Edisi 4. ANDI: Yogyakarta

Tjiptono, Fandy. (2008). Strategi pemasaran. Edisi 3. ANDI: Yogyakarta 